\title{
The Aid-Contracting Nexus: The Role of The International Contracting Industry in China's Overseas Development Engagements
}

Hong Zhang

\section{(2) OpenEdition}

Journals

Electronic version

URL: https://journals.openedition.org/chinaperspectives/11124

DOI: 10.4000/chinaperspectives. 11124

ISSN: 1996-4617

\section{Publisher}

Centre d'étude français sur la Chine contemporaine

\section{Printed version}

Date of publication: 1 December 2020

Number of pages: 17-27

ISSN: 2070-3449

\section{Electronic reference}

Hong Zhang, "The Aid-Contracting Nexus: The Role of The International Contracting Industry in China's Overseas Development Engagements", China Perspectives [Online], 2020/4 | 2020, Online since 01 December 2021, connection on 10 December 2021. URL: http://journals.openedition.org/ chinaperspectives/11124; DOI: https://doi.org/10.4000/chinaperspectives.11124 


\section{The Aid-Contracting Nexus: \\ The Role of the International}

Contracting Industry in China's

Overseas Development

\section{Engagements}

HONG ZHANG

ABSTRACT: Commercial interests in China's foreign aid projects are widely recognised in the literature. Yet, the role of the Chinese companies involved in such activities remains understudied. Piecing together information from primary sources, this article retells the story of China's overseas development engagements from the perspective of China's international contracting industry, the history of which is closely intertwined with China's foreign aid practices. Identified by the state to be a strategic vehicle for exporting Chinese labour, industrial products, technology, management skills, and capital, international construction contractors (ICECs) have received substantial policy support and have grown into prominent multinational corporations with global footprints. I use the concept of the "aid-contracting nexus" to highlight the linkage between China's economic diplomacy and domestic economic development strategy. The "aid-contracting nexus" provides a critical lens for analysing China's overseas development engagements, including why it has focused primarily on infrastructure, and the conceptual confusion over China's development finance. This analysis also speaks to the popular accusations that Chinese lending practices are predatory or "debt-trapping" by underscoring mercantilist logic as an alternative explanation. The evolving business model of ICECs is likely to pose new challenges for China's foreign relations.

KEYWORD: China, development finance, foreign aid, "Going out," infrastructure, international construction contracting, international development cooperation, SOE.

\section{Introduction}

That China's foreign aid has been largely driven by its commercial interests is widely recognised in the literature (Woods 2008; Tan-Mullins, Mohan, and Power 2010; Brautigam 2011; X. Li et al. 2014; Johnston and Rudyak 2017; D. Zhang and Smith 2017; M. Chen 2018; Morgan and Zheng 2019). The commercial turn followed a period of foreign aid provision largely motivated by ideological and geopolitical considerations during Mao Zedong's rule (1949-1976) and took shape when Deng Xiaoping's leadership (1978-1980s) placed China's domestic economic development firmly at the centre of the policy agenda. The commercial orientation was further amplified in the 1990s as a result of China's aid reform and the "Going out" (also known as "Going global") policy (Johnston and Rudyak 2017; Morgan and Zheng 2019). Nowadays, China's foreign aid is so closely linked with its trade and investment activities that it is believed to be re-defining international development cooperation (Gu et al. 2014; Lin and Wang 2016; Gu and Kitano 2018).
When analysing the mechanism underlying this distinct approach to international development, studies have shed great light on the role of policy banks, in particular the Export and Import Bank of China (CEXIM) and China Development Bank (CDB), in providing financial resources (Foster, Butterfield, and Chen 2009; Gallagher, Irwin, and Koleski 2012; Sanderson and Forsythe 2013; Kaplan 2016; M. Chen 2018; Chin and Gallagher 2019). While the financial institutions embody China's newfound financial power, they might not, however, be the primary driving force in China's phenomenal rise in international development. The analytical primacy placed on the financial institutions seems to have been informed by the traditional international development landscape, where international financial institutions such as the World Bank play an agenda-setting role, but there is no reason to assume the same dynamics in China.

Departing from the focus on financial institutions, this article spotlights the Chinese companies that carry out the Chinese-financed infrastructure projects, the indisputable focus of China's international 
development engagements (Foster, Butterfield, and Chen 2009; Bluhm et al. 2018; Bersch and Koivumaeki 2019). In this article I refer to them as China's international construction and engineering contractors (ICECS). Researchers have only begun to notice the ICECs' important role in China's international development engagements: Zhang and Smith (2017: 10-1) note in their study of China's foreign aid system that many aid projects are actually initiated by Chinese ICECS, which then lobby the Chinese government for financial and diplomatic support. Bersch and Koivumaeki (2019) find that in Latin America, China's ICECs are involved in many more major infrastructure projects than the policy banks are.

There are several reasons to expect Chinese ICECs to have greater agency than policy banks in shaping China's international development cooperation: first, the ICECs possess much greater knowledge about the overseas markets than the banks. As will be explained in greater detail later, ICECs pioneered China's venture into the international economy, leading the Chinese banks' overseas expansion by decades. By now, a great number of Chinese ICECs have established an expansive global presence, whereas the banks' overseas offices are still few (CEXIM has five overseas branches and CDB has ten). Second, due to the financing model, ICECS have been less concerned than banks about the fundamental viability of projects. Coupled with the fact that the banks are in a worse position than the ICECs to identify risk due to their sparse overseas presence, they may sometimes be misled by ICECS into financing undeserving projects.

China's international contracting activities are poorly understood in general. In Africa, for example, such activities are often mistaken for China's outward foreign direct investment (OFDI), creating the false impression that China has invested heavily in Africa. ${ }^{1}$ While OFDI involves taking whole or partial ownership in a project through the injection of financial capital, international contracting is essentially a form of service export. In fact, China's international contracting surpasses its OFDI globally (see Figure 1). While the largest destinations of Chinese OFDI are advanced economies, the leading markets of China's international contracting are all developing countries. ${ }^{2}$ Yet, scholarly investigations into China's contracting activities are still scarce, with the exception of a series by Chuan Chen and others on the overseas market-entering strategies of Chinese ICECs (C. Chen et al. 2007; C. Chen and Orr 2009; C. Chen, Goldstein, and Orr 2009; C. Chen et al. 2016). In the literature on China's international development engagements, a few scholars have acknowledged the role of ICECs (D. Zhang and Smith 2017; Brautigam and Hwang 2019; Morgan 2019), but none has placed the ICECs at the centre of the analysis.

This article fills in this gap by exploring the relationship between China's international contracting industry and China's practices in international development cooperation, which I encapsulate with the concept of "aid-contracting nexus." Based on an extensive review of Chinese policy documents, official yearbooks, and other primary Chineselanguage sources such as industry journals, I argue that China's rapid rise as a major development finance provider for infrastructure would not have been possible without the strong impulse to promote its international contracting industry, which was identified in the beginning of this century as a strategic vehicle for China's export-oriented economic development. China's strategic interests in international development are often interpreted as the need to obtain energy and raw materials, as reflected in the "infrastructure for resources" or "Angola model" (Corkin 2011; Alves 2013). My analysis, by contrast, frames the strategicness in terms of China's domestic development strategy. The focus on infrastructure in China's international development engagements is arguably an external manifestation of its industrial policy to foster

Figure 1. Steady growth of the international contracting industry (with outward foreign direct investment as comparison)

180

160

140

120

100

80

60

40

20

0

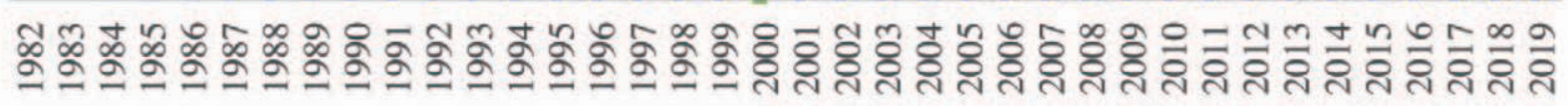

Realised contract value in international contracting $\quad$ OFDI

Sources:Yearbooks of Foreign Economy and Trade of China, 1984 to 2003; Yearbooks of Commerce of China, 2004 to 2016. Outward FDI data only available from 2003.

1. Thierry Pairault, "China in Africa: Goods Supplier, Service Provider Rather than Investor." International Centre for Trade and Sustainable Development, 5 July 2018, https://www.ictsd.org/ bridges-news/bridges-africa/news/china-in-africa-goods-supplier-service-provider-rather-than (accessed on 15 March 2020)

2. "China Clobal Investment Tracker," American Enterprise Institute, http://www.aei.org/china-globalinvestment-tracker/ (accessed on 20 January 2019). 
globally competitive industrial exporters at home. Highlighting how China's overseas development finance has been driven by these domestic concerns also helps explain its paradoxical largess in making financial resources available to other countries despite its relatively low per capita income. Some have suspected that China harbours an ulterior agenda, as seen in the "debt trap" accusations. ${ }^{3}$ But this paper will show that, rather than predatory - coercing the debtor into exploitative deals - China's practices might be better characterised as mercantilist - having a goal of maximising export for the sake of wealth accumulation.

While explicating the international contracting industry as the state's vehicle for its economic development strategy, this analysis also gives agency to the ICECS in how they make use of state support. They have drawn foreign aid as well as other types of state-backed finance for their international expansion, creating challenges that might not have been foreseen by the state. This analysis echoes the arguments about the dynamic and negotiated relationship between the Chinese state and state-owned enterprises (SOEs) in the literature (Liou 2009; Jones and Zou 2014, 2017).

This article is organised as follows: in the first section, I trace the history of China's international contracting industry in relation to China's foreign aid practices, and how the industry rose from a base of zero to become a prominent global player within three decades under the state's strategic support. I go on to discuss the ICECs' status as "national champions" in the Chinese political economy in the second section. Third, I explain how ICECs have been responsible for mixing China's foreign aid with other types of finance, leading to confusion over the scale of China's foreign aid and moral hazard. Finally, I analyse how the ICECs' evolving business model is mobilising a variety of state-backed financial resources, which seems to be driving some conceptual innovation about "development finance" in China. In conclusion, I discuss the implication of these developments for the relationship between the state and the ICECs.

\section{Aid-contracting nexus: The rise of China's international contracting industry}

China's active provision of foreign aid dates back to the 1950s. Driven by the desire to win diplomatic support as well as an ideological contest with both the United States and the Soviet Union, China went out of its way to provide foreign aid to African countries in the 1960s and 1970s, despite being a very poor country itself (Huang and Ren 2012; Jiang 2019). Foreign reserve-strapped and locked out of the international market, China could not afford to offer foreign aid in the form of financial transfer (Li et al. 2014: 25); instead, it had to do it in the form of turnkey projects, in which China sent engineers and technicians to construct infrastructure or productive facilities, paid for by the Chinese government. This mode of foreign aid provision persists even now, and is the beginning of the aid-contracting nexus story to be introduced here.

Under the command economy during Mao's rule, such turn-key projects were delivered by designated units within China's various line ministries and subnational governments (Zhou and Xiong 2013: 4). For example, the construction of the famous Tanzania-Zambia Railway was organised by the foreign aid office under China's Ministry of Railways. As Deng Xiaoping took the helm in the late 1970s and started to shift the policy agenda toward economic development, ill-afforded foreign aid was scaled back, and more consideration was placed on the financial sustainability of aid provision. Economic incentives were deployed to improve efficiency in the use of foreign aid. A major national conference on foreign aid in 1983 decided that aid delivery entities would be allowed to retain unused funds if they managed to complete the projects below budget. ${ }^{4}$ As such, China effectively turned foreign aid projects into forprofit business opportunities.

Meanwhile, aid-delivering entities, previously administered by China's line ministries and subnational governments, ${ }^{5}$ were stripped from the government and incorporated into firms as part of the reform to separate enterprises from the administration in the 1980s and 1990s. For example, the foreign aid offices under the Ministry of Railways, Ministry of Transportation, and Ministry of Water Resources and Hydraulic Power were restructured into China Civil Engineering Construction Corporation, China Road and Bridge Corporation, and China International Water and Electric Corporation, respectively. Similarly, the foreign aid divisions of each provincial government were also integrated into newly established firms mandated to engage in foreign trade. Nowadays, any Chinese SOE whose name contains the term "international economic and technology cooperation" (國際經濟技術合作 guoji jingji jishu hezuo) is almost certain to have a predecessor that was a foreign aid delivery unit in a subnational government or a line ministry. While these firms continued to carry out foreign aid projects for the government, their primary purpose had changed: to open up overseas markets and earn foreign exchange, which China was hungry for in those early days of economic transition.

As China opened itself up in the 1980s, these former aid delivery units were virtually the only companies with any on-the-ground experience overseas, thanks to their previous undertakings of turn-key aid projects. They were thus expected to lead the exploration into the international markets. Their experience in building foreign aid projects naturally led them into the business of construction and engineering contracting. Oilproducing countries in the Middle East (especially Iraq) were among the first target markets of start-up ICECs. With reasonable skills and low costs, the Chinese ICECs found themselves rather welcomed and enjoyed some immediate success.

From a base of non-existence, the Chinese ICECs rose rapidly to prominent positions in the world market. As shown in Figure 1, China's international contracting industry has enjoyed steady growth since the early 1980s. By 2015, the size of the industry (by revenue in current dollars) was over 800 times of that in 1982. By 2018, 75 of the world's top 250 international contracting firms were Chinese, ${ }^{6}$ claiming $24.4 \%$ of the world's international contracting revenue. The share is even higher in Africa (60\%) and Asia excluding China (40\%) (Kurimoto 2019). ${ }^{7}$ Figure 2 shows China's market share in international contracting by region. China became the largest player in Africa as early as 2006. In Asia, the Middle East, and Latin America and the Caribbean, China also either claims first place or comes a close second.

3. Brahma Chellaney, "China's Debt-Trap Diplomacy," Project Syndicate, 23 January 2017, https:// www.project-syndicate.org/commentary/china-one-belt-one-road-loans-debt-by-brahmachellaney-2017-01 (accessed on 2 September 2020)

4. “1978-1999年, 中國對外經濟技術援助的改革發展階段” (1978-1999 nian, Zhongguo duiwai jingji jishu yuanzhu de gaige fazhan jieduan, Reform and development of China's foreign economic and technical assistance, 1978-1999), Ministry of Commerce of People's Republic of China, undated, http://history.mofcom.gov.cn/?specialfive=zgdwjjzsyzdggfzjd (accessed on 12 September 2019)

5. For the role of subnational governments in China's foreign aid, see Shi and Hoebink (2020).

6. "ENR's 2019 Top 250 International Contractors," ENR, https:/www.enr.com/toplists/2019-Top250-International-Contractors-1 (accessed on 30 March 2020).

7. Suguru Kurimoto, "Belt and Road Propels Chinese Contractors to Top of Global Ranks," Nikkei Asian Review, 19 September 2019, https://asia.nikkei.com/Spotlight/Belt-and-Road/Belt-and-Roadpropels-Chinese-contractors-to-top-of-global-ranks (accessed on 2 September 2020). 


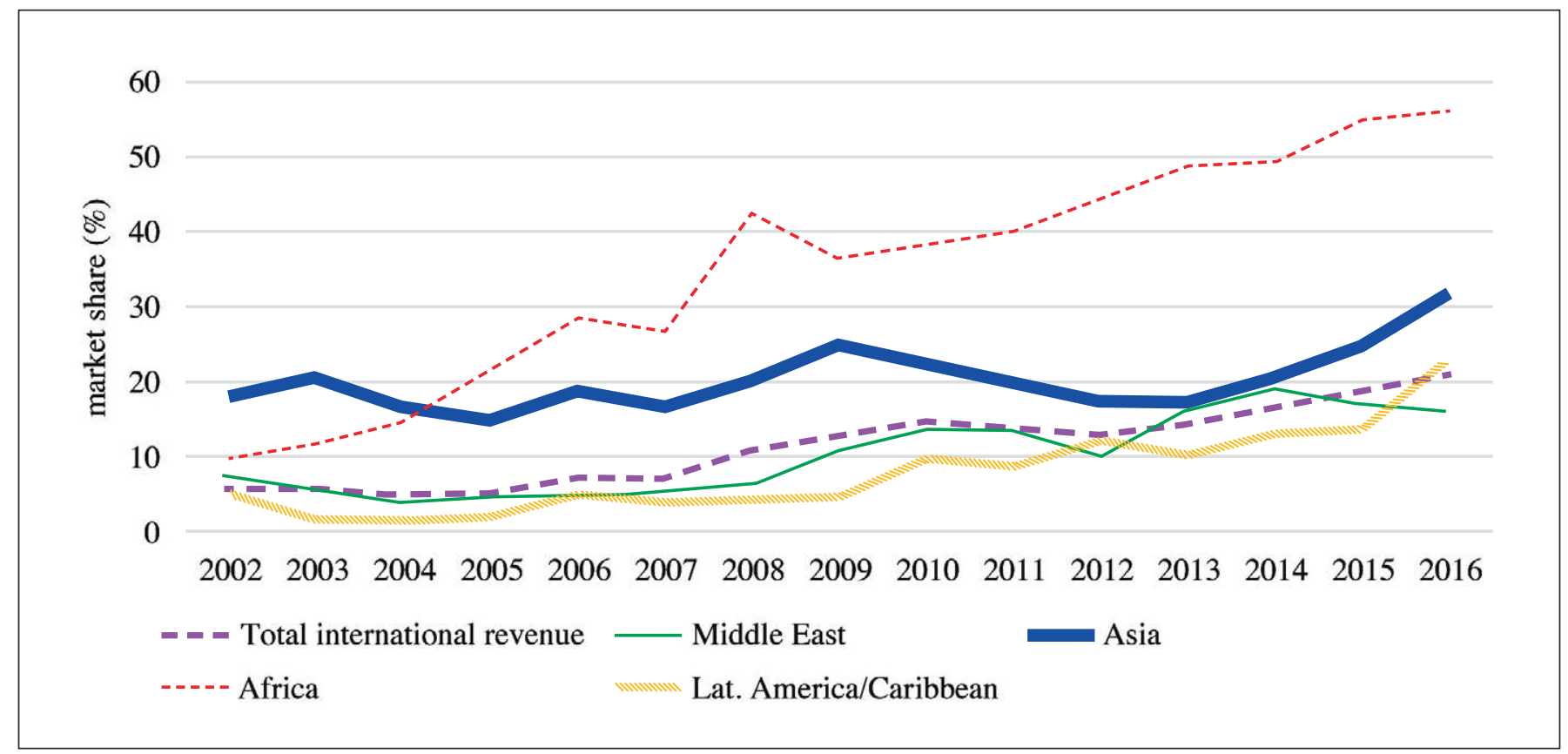

Source: Author's compilation based on ENR Top 225/250 International Contractors, 2003-2017.

How was this rags-to-riches story possible? An obvious part of the reason lies in the demand side: there is tremendous demand in the developing world for infrastructure and construction, which the Chinese ICECs simply tapped into. But below I will show that the Chinese government's proactive policy support was also crucial. Policies were not only focused on growing the size of the industry, but also rather methodical in guiding industrial upgrading.

The development of China's international contracting industry can be divided into three periods: 1) nascency in the 1980s, 2) formative years in the 1990s, and 3) leapfrogging growth after 2000. The 1980s saw Chinese ICECs entering the world markets largely as subcontractors in larger projects, carrying out less sophisticated, labour-intensive portions of the construction work. Indeed, the contracting service in this period was essentially export of construction labour. Starting from this period, foreign aid has been purposefully used to support ICEC market exploration by financing preparatory work (Yearbook 1989: 55).

During the 1990s, the Chinese government became more proactive in regulating and shaping the industry. Recognising that the labour-intensive contracting in which Chinese ICECs had engaged so far was low value-added, the government encouraged larger industrial companies and design institutes with more sophisticated technological capabilities to enter the business and lead the industrial upgrading. These companies were given priority when granting licenses (Yearbook 1992, 1994). As such, the government was pushing for a transition from labour-intensive contracting service toward greater technology intensity. Another important motivation for pushing the larger companies to compete for international contracts was that, as general contractors, they could make procurement decisions and source from China. The idea that ICECs could serve as a vehicle for exporting China's industrial goods started to take root (Yearbook 1997: 73). Industrial firms in sectors with surplus production capacity such as power generation, textiles, railways, oil, and forestry were encouraged to seek overseas market outlets via international construction and engineering contracting (Yearbook 2000: 65).

As the number of ICECs mushroomed during the decade (by 1998, 955 companies had been licensed for international contracting), the government pushed for consolidation. In line with China's general SOE reforms in this period, restructuring in this industry followed a "pro-big business" guideline (C. Li 2016). Larger companies believed to be more capable of competing internationally were to be given favourable policy treatment (Yearbook 2000: 65). Meanwhile, the government not only continued to support the industry through utilising foreign aid (Yearbook 1997: 74; 1998: 71), but also became more entrepreneurial in facilitating market exploration. For instance, what was then the Ministry of Foreign Economy and Trade organised study tours to key target countries; central leaders took business delegations to regional meetings in Africa and the Middle East to promote their market entry (Yearbook 1996: 69-70).

The year 2000 was pivotal for China's international contracting industry. As China was preparing to join the World Trade Organization, policymakers took a long look at how Chinese industries could thrive in the global economy. It was at this critical juncture that international contracting was identified as a strategic vehicle for China's "Coing out" policy. In 2000, China's State Council forwarded a landmark directive titled "Opinions for Vigorously Promoting the Development of International Contracting" to all subnational governments, line ministries, and government agencies, signalling its significance. The elevated importance attached to the international contracting industry warrants quoting in full:

...all regions and all government organs must fully recognise the importance of developing international contracting from a political height and an understanding of the big picture, and make sure to develop international contracting as an important measure to implement the Central Government's "Going out" strategy. We should clearly understand that, under the current situation, developing international contracting will help promote our exports and accelerate our transition toward a trading superpower from merely a large trading nation; it will facilitate the utilisation of both domestic and overseas resources and markets, transferring abroad surplus engineering capacity from home; it will help our enterprises to "go out" and integrate into 
economic globalisation, cultivate our own multinational corporations and enhance our international competitiveness; it will help improve our political and economic relations with foreign countries, especially relations with developing countries. ${ }^{8}$

To facilitate the ICECs' overseas market expansion, the directive explicitly urges all parties to "take full advantage of the extensive influence" of China's foreign aid among the developing countries as part of the "Broad-Based Strategy of Foreign Trade and Economic Cooperation" (Dajingmao zhanlüe 大經貿戰略) (Yearbook 1995: 18-25; see also: Johnston and Rudyak 2017: 438; Shimomura and Wang 2018: 34). The directive further authorises a set of financial measures to support international contracting, including providing bank guarantees, insurance, subsidised working capital loans, eased loan conditions, and international fund-raising. In particular, international contracting projects that source machinery and materials substantially from China (over $15 \%$ of the contract value) are given additional support, reflecting the overall policy goal to promote the export of China's industrial goods (reflecting this objective, ICECS are required to report the value of exported goods enabled by their overseas projects as part of their routine reports to the Ministry of Commerce). ${ }^{9}$

To follow up with this high-level directive, a series of tools were launched by the financial authorities over the next few years (Table 1). It is worth noting that the 2003 policy specifically encouraged ICECs to compete for international projects by "bringing in financial resources" (帶資 daizi), which the government instructed financial institutions to make available. ${ }^{10}$ The ICECs were urged to "apply for hybrid loans including commercial loans, policy export credits, and other special funds." As will be elaborated in the next section, the promise to bring in financial resources from China became a key strategy for the international expansion of Chinese ICECS.

Table 1. Policy measures supporting international contracting

\begin{tabular}{ll}
\hline Year of policy & Policy tool \\
announcement &
\end{tabular}

2001 A special fund is set up, administered by the Bank of China, to provide bank guarantees and cover financial risks for larger international contracting projects (over $\$ 5$ million).

2001

The central government budgets special funds to subsidize interest payment for working capital loans associated with international contracting projects. The policy seems to be effective from 2001 to 2005 , before being replaced by other policy tools.

2003 The CEXIM and commercial banks are to accommodate loan requests from ICECs whose overseas projects contain export of Chinese goods, technology, management and labor worth over 15 percent of the contract value.

Sources: Compiled by the author from the State Council and Ministry of Commerce.

Riding on these policies, China's international contracting industry not only burgeoned in terms of size, but also gradually climbed up the value chain. The top contributing sector in China's international contracting has moved from building construction, which requires relatively low levels of technology and project management skills, toward more complex infrastructure and industrial sectors such as petrochemical, transportation, power generation, and telecom. In this process, ICECs are instrumental in channelling Chinese industrial products and technology (in addition to labour and capital) into international markets, especially the developing world, linking them up with China's industrial system.

This has come to define China's focus on international development cooperation, i.e., the focus on industrialisation-enabling infrastructure. While many have pointed out that this mirrors China's domestic development experience of investing heavily in infrastructure, the above analysis suggests that this is not simply out of habit; rather, it has been guided by a specific strategy to export China's industrial goods and technology through construction and engineering contracting. This development strategy has been a necessary condition for China to focus on the infrastructure sector, which distinguishes it from the other similarly ambitious "emerging donors" such as Brazil and India, which lack a similarly well-organised contracting industry and articulated strategy.

I call this connection between China's economic diplomacy and industrial policy the aid-contracting nexus. For the actors within this nexus, the growing reach of the international contracting industry is the immediate concern, while the development of the host countries is not necessarily carefully considered, and diplomatic considerations are relegated to the background. This economic explanation is not to negate the importance of politics in China's foreign aid policymaking; as Zhang and Smith (2017) have argued, the Ministry of Foreign Affairs' role in aid policymaking should not be overlooked, and politics is still pivotal. But while politics lays out the contour of China's foreign aid allocation, the aid-contracting nexus determines how the largest amounts of aid are used.

\section{Powerful national champions}

To illustrate the prominence of ICECS in the Chinese political economy, Table 2 lists the ten largest ICECS according to their international revenue in 2019, ranked by the Engineering News-Record (ENR), an authoritative publication in the construction industry. All of the top ten ICECs are among China's 96 SOEs administered by the State-owned Asset Supervision and Administration Commission of the State Council (SASAC), or central SOEs. Their core businesses span across industrial and infrastructural sectors (but their international contracting activities are far from confined to their core sectors). Some of these SOE groups resulted from mergers of SOEs that were prominent ICECS in their own right (e.g., China Road and Bridge Corporation and China Harbour Engineering Company were both already leading players in the road and harbour construction sectors before they were merged into China Communications Construction Group) as part of the state-directed industry consolidation, which makes these companies' market positions even more unassailable.

8. “關于大力發展對外承包工程的意見” (Guanyu dali fazhan duiwai chengbao gongcheng de yijian, Opinions for greatly promoting the development of international contracting), Ministry of Foreign Economy and Trade, Ministry of Foreign Affairs, National Planning Commission, National Commission of Economy and Trade, Ministry of Finance, and People's Bank of China, 17 March 2000, http://www.gov.cn/zhengce/content/2010-12/30/content_4599.htm (accessed on 20 January 2019).

9. “商務部關于印發 “對外承包工程業務統計調查制度' 和 ‘對外勞務合作業務統計調查 制度' 的通知" (Shangwubu guanyu yinfa "duiwai chengbao gongcheng yewu tongji diaocha zhidu" he "duiwai laowu hezuo yewu tongji diaocha zhidu" de tongzhi, Ministry of Commerce's notice on publishing "rules for reporting overseas contracting statistics" and "rules for reporting overseas labour service cooperation statistics"), Ministry of Commerce, 2019, http://hzs.mofcom. gov.cn/article/zcfb/a/201901/20190102827146.shtml (accessed on 27 May 2019).

10. “對外貿易經濟合作部, 財政部, 中國人民銀行關于支持我國企業帶資承包國外工程 的若干意見" (Duiwai maoyi jingji hezuo bu, caizheng bu, Zhongguo renmin yinhang guanyu zhichi woguo qiye daizi chengbao guowai gongcheng de ruogan yijian, Opinions on supporting companies taking part in international contracting with financing by the Ministry of Foreign Trade and Economic Cooperation, Ministry of Finance, and People's Bank of China), Ministry of Commerce, 14 March 2003, http://file.mofcom.gov.cn/article/gkml/200804/20080493512263. shtml (accessed on 20 June 2020). 
Table 2. Ten Chinese ICECs ranked among the top 50 in the ENR Top 250 International Contractors in 2019

\begin{tabular}{|c|c|c|c|c|}
\hline Group Company & ENR Ranking & Core sector & Background & Notable subsidiaries \\
\hline $\begin{array}{l}\text { China Communications } \\
\text { Construction Group }\end{array}$ & 3 & transportation & Central SOE & $\begin{array}{l}\text { China Road and Bridge Corporation; } \\
\text { China Harbour Engineering Company }\end{array}$ \\
\hline Power Construction Corp. of China & 7 & power generation & Central SOE & Sinohydro Corporation \\
\hline $\begin{array}{l}\text { China State Construction } \\
\text { Engineering Corp. }\end{array}$ & 9 & construction, real estate & Central SOE & \\
\hline $\begin{array}{l}\text { China Railway } \\
\text { Construction Corp. }\end{array}$ & 14 & railway & Central SOE & $\begin{array}{l}\text { China Civil Engineering } \\
\text { Construction Corporation }\end{array}$ \\
\hline China Railway Group & 18 & railway & Central SOE & \\
\hline $\begin{array}{l}\text { China National Machinery } \\
\text { Industry Corp. (Sinomach) }\end{array}$ & 19 & industrial engineering & Central SOE & China CAMC Engineering Co. Ltd. \\
\hline China Energy Engineering Corp. & 23 & power generation & Central SOE & Gezhouba Group \\
\hline $\begin{array}{l}\text { China National Chemical } \\
\text { Engineering Group Corp. }\end{array}$ & 29 & chemical engineering & Central SOE & China Chengda Engineering Co. Ltd. \\
\hline $\begin{array}{l}\text { China Petroleum } \\
\text { Engineering Co. }\end{array}$ & 43 & oil and gas engineering & $\begin{array}{l}\text { Subsidiary of China } \\
\text { National Petroleum Corporation } \\
\text { (CNPC), a central SOE }\end{array}$ & \\
\hline China Metallurgical Group Corp. & 44 & metallurgical & Central SOE & \\
\hline
\end{tabular}

Source: ENR, author's compilation.

It should be noted that while these SOEs are leading international contractors, a much greater share of their business is in China. Many of them enjoy monopoly status domestically in their sectors (such as oil and gas, and railways). Even in highly competitive sectors such as construction, central SOEs still command a formidable share. They are the "national champions" intentionally created by China's SOE reforms to act as "instruments of state policy" that "can be set forth to battle for objectives the national government wants to achieve" (Naughton 2015: 66). Indeed, their ventures into international contracting have been both backed by their domestically developed capacities and motivated by the desire to export these capacities abroad. But contrary to Naughton's argument that these "national champions" are not very important in China's export-oriented economic development, this analysis of their international contracting shows that they are.

The Chinese ICECs' power stems not only from the fact that the majority of them are SOEs, but also from being well organised as an industry. The China International Contractors Association (CHINCA), the industry's national chamber of commerce, was established in 1988 and now boasts a membership of more than 1,500. ${ }^{11}$ Steering the association are 43 of China's largest ICECs as well as the financial institutions that play critical roles in supporting international contracting. ${ }^{12}$ In addition, there are also provinciallevel associations in some provinces with a heavy presence of ICECs (e.g., Shandong and Anhui). Rather than autonomous associations of the ICECS, these organisations are better understood as semi-official regulatory bodies of the industry. CHINCA has been instructed by the government to coordinate the pricing and market development among the ICECs (Yearbook 1996: 69-70). CHINCA's statement of support, along with that from the Chinese embassy, was required for ICECs to apply for financing from China's policy banks (Chen and Orr 2009: 1204). These associations also serve to coordinate government-industry relations. The leadership positions are typically occupied by current or retired officials from the Ministry of Commerce. This on the one hand helps ensure easy access for lobbying, and on the other hand gives the government direct influence over the industry.

\section{Blurring the line between aid and other finances}

Earlier I discussed how the Chinese state proactively support the international contracting industry, including instrumentalising foreign aid. This section turns to the agency of the ICECs themselves. Encouraged by the state's policy, they mix aid with various types of finance to fuel their international expansion. As an unintended consequence, this has led to confusion over the scale of China's foreign aid. Put under the spotlight, China has responded by trying to articulate a new concept of "development finance" that challenges the traditional notion of official development assistance (ODA). I therefore argue that the key to solving the conceptual puzzle of China's development finance, rather than focusing on the modality of the finances per se, is to pay attention to the agency of the ICECs. It is them who provide the improvisation and momentum for the changing concept of development finance in China.

Supported by the state to compete for international projects through "bringing in the finance," as alluded to earlier, Chinese ICECs have drawn from various sources for their international expansion, often mixing them together for the same projects. For instances, the Mtwara-Dar es Salaam gas pipeline in Tanzania seems to be funded by both a foreign aid concessional loan and preferential buyer's export credit. ${ }^{13}$ Bui Dam in Ghana was funded

11. "About Us," CHINCA, http://www.chinca.org/CICA/PresidentSpeech/Detail/17102414503811 (accessed on 27 May 2019).

12. "Members with vice president status," CHINCA, http://www.chinca.org/CICA/ info/19040917150211 (accessed on 27 May 2019).

13. “坦桑尼亞總理平達視察我援坦姆達天然氣管道項目” (Tansangniya zongli Pingda shicha wo yuan tan muda tianranqi guandao xiangmu, Tanzanian Prime Minister Pinda inspects Chineseaid Mtwara-Dar es Salaam Natural Gas Pipeline Project), Ministry of Commerce of People's Republic of China, Department of Foreign Assistance, 2 July 2014, http://yws.mofcom.gov.cn/ article/b/201407/20140700648587.shtml (accessed on 28 July 2019); "駐坦桑尼亞大使呂 友清在姆特瓦拉達市天然氣管道啓用儀式上的講話” (Zhu Tansangniya dashi Lü Youqing zai mutewalada shi tianranqi guandao qiyong yishi shang de jianghua, Chinese Ambassador to Tanzania Lu Youqing delivers speech at the inaugual ceremony of Mtwara-Dar es Salaam Natural Gas Pipeline), Ministry of Foreign Affairs of People's Republic of China, 13 October 2015, https:// www.fmprc.gov.cn/web/gjhdq_676201/gj_676203/fz_677316/1206_678574/1206x2_678594/ t1305535.shtml (accessed on 28 July 2019). 
by a mix of concessional and commercial loans (Yankson et al. 2018), so was the Addis Ababa-Djibouti railway in Ethiopia (Morgan and Zheng 2019). As Chinese ICECS themselves often advertise, their ability to obtain financing from Chinese financial institutions is a key source of their competitiveness (Brautigam and Hwang 2019: 325). African officials also acknowledge that Chinese ICECs' ability to secure financing is an important reason for them winning contracts (Chin and Gallagher 2019: 259). The withdrawal of traditional donors from infrastructure financing in recent decades (Tierney et al. 2011: 1898) only makes China's impact in this field even more conspicuous.

Among the various forms of finance, China's foreign aid concessional loans and preferential buyer's export credits (PBECs) are especially important for Chinese ICECs to obtain contracts for large-scale infrastructure projects. These two types of loans have financed, or partly financed, some of the most high-profile projects involving China across the developing world, such as the standard-gauge railway in Kenya and the Hanbamtota port in Sri Lanka. This is because the lower rates and longer terms of the PBECs and foreign aid concessional loans make them preferable for larger infrastructure projects, which entail long construction periods and substantial operational risks. The inter-governmental nature of these loans gives the ICECs additional political protection in case of any dispute that arises in the process of project implementation. Conversely, PBECs and foreign aid concessional loans are also procedurally the most demanding compared to other types of financing provided by Chinese banks. Therefore, known cases of these loans seem to mostly go to projects involving leading SOEs as contractors.

Although the borrower in both foreign aid concessional loans and PBECs is technically the government of the host country, it is the Chinese ICECs eyeing the contract that drive the borrowing process. As shown in Figure 3, the contractor company is a necessary party for the initiation of the borrowing process of both types of loans. Therefore, while the available quotas of foreign aid concessional loans and PBECs for each country are set by China's political leadership based on foreign policy considerations, the successful utilisation of these loans usually is the result of the Chinese ICECs' work on the ground. Discussions among industry insiders corroborate this. For example, as an employee of a Chinese ICEC writes on the industry's main journal to share their success story in obtaining both foreign aid concessional loans and PBECs in Ghana, it is the prospective contractor's job to coordinate between the two governments for the required inter-governmental framework agreements and to submit the loan requests to the CEXIM (Bian 2013: 49).

Figure 3. CEXIM's lending procedure of foreign aid concessional loans (FACLs) and preferential buyer's export credits (PBECs)

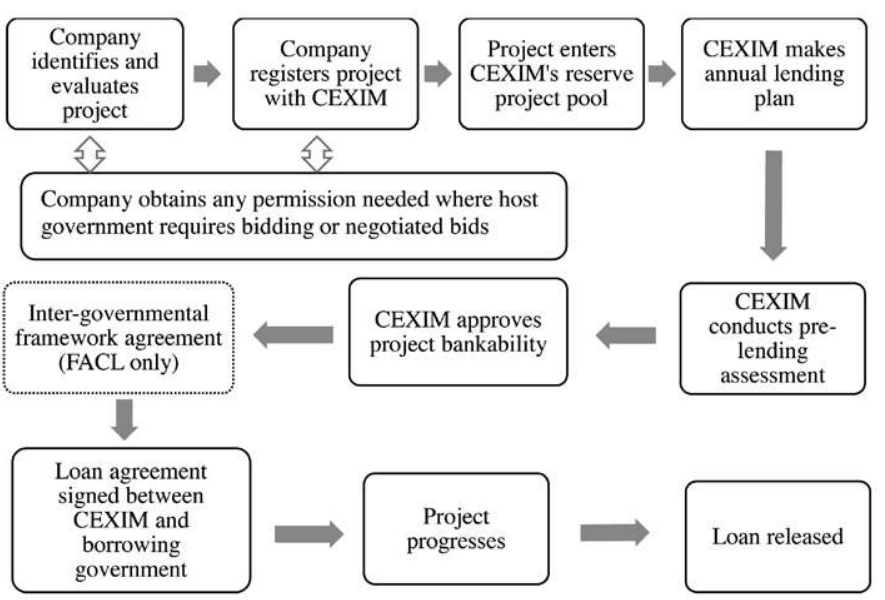

Source: Adapted from an internal presentation by CEXIM's Preferential Loan Department.
As further evidence of ICECs' agency in seeking to shape China's foreign aid and other finances to suit their interests, there are recurrent calls from ICECs for greater financial support from the state. For instance, some have advocated lowering the interest rates of policy loans, as they are not as competitive as the loans provided by Japan, viewed as a chief rival (Chang 2015; Jiang 2016); some suggest that China should make the adoption of Chinese technical standards in infrastructure and industrial projects a condition for Chinese loans, as they find it frustrating to be required by project owners to follow US, European, and Japanese standards (Liu 2015: 66; Sun 2015: 65).

However, this financing model can induce moral hazard. As contractors, the companies bear little responsibility for the underlying economic viability of a project, which ultimately determines whether it can generate enough revenue in time to repay the loans. This creates incentives for Chinese ICECS to pursue risky projects that other donors or creditors have shunned, as long as they can help secure financing from China. The controversial Hambantota Port, built by China Harbor Engineering Company, which helped lobby for financing from China, is a case in point (Zhang 2019). Moreover, because many such loan agreements are backed by resources - Chin and Gallagher (2019) find that half of the lending by Chinese development banks are backed by commodities ranging from oil, copper, and diamonds to cocoa it has created the impression that China lends predatorily with an ulterior motive to seize collateralised assets. Some have accused China of engaging in "debt-trap diplomacy."

However, a more accurate explanation of the phenomenon may be that, because ICECs bear little financial risks in this financing model, they may overstate the case for a potential project and encourage the host government to seek financing from China. The Chinese banks, on the other hand, may not have adequate local knowledge to make a sound assessment of the project's risks. When the project runs into financial trouble, both the banks' balance sheets and the Chinese government's reputation (due to the inter-governmental nature of the loans) suffer. Moreover, since the Chinese ICECS are the reason financing could be obtained from China, they are often granted contracts without going through a rigorous tendering process. Unsurprisingly, such practices have led to perceptions of corruption and public backlash.

The common practice by ICECs of mixing different types of loans has also resulted in confusion over the scale of China's foreign aid, which is often drastically overestimated by outside observers ${ }^{15}$ (for a critique, see Brautigam 2010). Much of the confusion seems to stem from the similarities between foreign aid concessional loans and PBECs. According to the official White Paper on China's Foreign Aid, the Chinese government does not consider PBECs part of its foreign aid. ${ }^{16}$ While the capital for both types of loans are raised by the CEXIM from the financial markets, the government subsidises the gap between the fund-raising costs and lending rates for the foreign aid concessional loans from its aid budget, but not the PBECs. In practice, however, they are very similar. Both are issued by the CEXIM (with even

14. Brahma Chellaney, "China's Debt-Trap Diplomacy," Project Syndicate, 23 January 2017, https:// www.project-syndicate.org/commentary/china-one-belt-one-road-loans-debt-by-brahmachellaney-2017-01 (accessed on 2 September 2020); "Lessons from Sri Lanka on China's 'DebtTrap Diplomacy'," ISSAfrica.org, 21 February 2018, http://iss.curo.co.za/amp/iss-today/lessonsfrom-sri-lanka-on-chinas-debt-trap-diplomacy (accessed on 2 September 2020).

15. For a critique, see Deborah Brautigam, "Billions in Aid?," 27 February 2010, http://www. chinaafricarealstory.com/2010/02/billions-in-aid.html (accessed on 2 September 2020).

16. "White Paper on China's Foreign Aid," Information Office of the State Council, People's Republic of China, April 2011, http://english.www.gov.cn/archive/white_paper/2014/09/09/ content_281474986284620.htm (accessed on 15 June 2020). 
the same Preferential Loan Department within CEXIM in charge of them); both carry low interest rates with a long duration and a grace period; both are supposed to serve diplomatic purposes. The only differences between them are that a foreign aid concessional loan is issued in Chinese yuan while a PBEC is issued in US dollars, and they have different requirements for matching funds from the borrowing government. ${ }^{17}$ Consequently, media reports and research often fail to distinguish between the two, referring to both as "concessional loans." Even in AidData, ${ }^{18}$ a widely used database that has taken great care to differentiate between ODA-like finance and "other financial flows," loans that appear to be PBECs (as they are issued in US dollars) are classified as "ODA-like." To add to the confusion, even Chinese officials have sometimes mixed them up. A known example is the Chinese embassy in Cambodia: when reporting foreign aid figures to Cambodia's aid management authority, they include PBEC-financed projects as well. ${ }^{19}$ As the amount of PBECs has exceeded China's bilateral foreign aid (including concessional loans, grants, and interest-free loans) since 2012 (Kitano's 2018), this has led to overestimation of China's foreign aid and by implication, skewed assessment of China's foreign policy intentions.

\section{From builders to developers}

The availability of loans has enabled the expansion of Chinese ICECS based largely on a business model of Engineering-Procurement-Construction (EPC) contracting. After decades of growth, however, the EPC model is gradually losing steam due to a number of structural reasons: intense competition among Chinese ICECS squeezes the margin to unprofitable levels; rising labour costs in China erode their cost advantage; the leeway for governments of developing countries to borrow from China is shrinking due to their elevated levels of indebtedness.

The industry's response to diminishing EPC opportunities has been to move from the role of simply "builders" to "developers" (Editorial Board 2011). The current mantra in the industry is "integrated investment, construction, and operation" (tou jian ying yitihua 投建營一體化, IICO), which was also endorsed as a model for Chinese companies to participate in Africa's infrastructure development by Chinese president Xi jinping during the 2018 Forum on China-Africa Co-operation. ${ }^{20}$ This means that ICECS are looking to extend their activities to both the front and the back ends of the value chain. On the one hand, they seek to be more proactive in the planning, design, and initiation of new projects rather than simply bidding for those that have been planned out; on the other hand, they will be involved in the operation and management of projects after having built them. To do this, ICECs will have to take ownership in the projects as investors rather than simply acting as hired contractors.

An example of the IICO model is the Addis Ababa-Djibouti railway: China Civil Engineering and Construction Corporation (CCECC) was involved in the pre-construction design, the actual construction, and the post-construction operation. The project drove nearly $\$ 400$ million of Chinese exports to Africa and adopted Chinese technical standards. ${ }^{21}$ Notably, besides making use of a $\$ 2.5$ billion loan provided by the CEXIM, CCECC also invested its own capital in Djibouti's railway sector, as well as in real estate development along the rail line in order to boost its commercial value. ${ }^{22}$ This model of "whole value chain going out" is boasted to be an exemplar for other Chinese ICECS to follow. The movement seems already well under way, and not just in Africa. As Bersch and Koivumaeki (2019: 334) find through their examination of Chinese involvement in key infrastructure projects in Latin America, "Chinese government and companies more frequently take an integrated approach, maintaining control over projects from planning to execution."

Therefore, we are likely to see Chinese ICECs, in particular the larger ones, increasingly take on equity investment in their pursuit of overseas contracts, which will require different types of financing than the traditional foreign aid loans and export credits (Wang 2018). In addition to the CEXIM and China Development Bank, the two policy banks that have traditionally played, and will continue to play, important roles in supporting the "Going out" of Chinese companies, China has also set up a number of investment funds in recent years that are designed to support equity investment (see Table 3). These funds can be understood as sovereign wealth funds-cum-development funds. Like the foreign aid-export credit mix, the hybridity of these funds will again complicate the nature of China's economic engagement with other developing countries.

The ICECs' evolving business model is also driving conceptual innovation in China regarding what can be considered "development finance." An influential book by former World Bank Vice President Justin Yifu Lin and co-author Yan Wang suggests a tiered concept of development finance: traditional overseas development assistance (ODA), as defined by the Organisation of Economic Co-operation and Development's Development Assistance Committee, will be merely the narrowest sense of development finance (DF1); the broader sense of development finance will also include preferential export buyer's credits (DF2), non-concessional loans from state entities for development purposes (DF3), equity investments by sovereign wealth funds, development projects supported by state guarantees, and public-private partnership (PPP) projects for public infrastructure (DF4) (Lin and Wang 2016). It should be obvious from the above analysis that these categories reflect the various sources of state-backed finance the Chinese ICECs have drawn.

\section{Conclusion and discussion}

This article zooms in on the role of Chinese ICECs in China's international development engagements. I use the concept of "aid-contracting nexus" to highlight the linkage between China's economic diplomacy and its industrial policy to promote export-oriented development in its heavy industries, in which international contracting serves as a strategic vehicle. Given privileged policy support, Chinese ICECs have been proactively drawing various statebacked financial resources to fuel their international expansion. They have now become leading players in the market of international contracting, especially in Africa.

The political economy of the international contracting industry thus provides another critical lens for understanding China's international

17. “中國進出口銀行'兩優'貸款介紹” (Zhongguo jinchukou yinhang 'liangyou' daikuan jieshao, Introduction of the government concessional loan and preferential buyer's credit), Exim Bank of China, Concessional Loan Department, 11 December 2013, http://www.chinca.org/cms/html/fil es/2013-12/16/20131216102948872930302.pdf (accessed on 20 January 2019).

18. "AidData's Clobal Chinese Official Finance Dataset, 2000-2014, Version 1.0," AidData.

19. Cambodian Rehabilitation and Development Board, Council for the Development of Cambodia, "The Cambodia ODA Database," http://odacambodia.com/ (accessed on 15 July 2019).

20. “習近平: 未來對非重點實施 '八大行動”' (Xi Jinping: weilai dui fei zhongdian shishi "bada xingdong," Xi Jinping: "Eight major actions" to be taken in Africa in future), Xinhua Net, 3 September 2018, http://www.xinhuanet.com/silkroad/2018-09/03/c_129946121.htm (accessed on 20 June 2020).

21. Yunnan Chen, "Railpolitik: The Strengths and Pitfalls of Chinese-Financed African Railways," Panda Paw Dragon Claw (blog), 16 March 2020, https://pandapawdragonclaw.blog/2020/03/16/ railpolitik-the-strengths-and-pitfalls-of-chinese-financed-african-railways/ (accessed on 2 September 2020).

22. Zha Yin 查殷, “亞吉模式領跑'絲路'建設” (Yaji moshi lingpao 'silu' jianshe, Addis-Djibouti model leads "silk road" development), Guoji gongcheng yu laowu, 14 November 2016, http:// www.chinca.org/IEAService/info/20161114090046 (accessed on 29 May 2019). 
Table 3. Chinese state-backed funds for supporting investment in industrial development in developing countries

\begin{tabular}{|c|c|c|}
\hline Development fund & Year launched & Capitalization \\
\hline China-Africa Development Fund & 2007 & \$5 billion (2007-2015); $\$ 10$ billion (since 2015). \\
\hline China-ASEAN Investment Cooperation Fund & 2009 & $\$ 10$ billion (initial capitalization $\$ 1$ billion) \\
\hline Silk Road Fund & 2014 & $\begin{array}{c}\$ 40 \text { billion + } ¥ 100 \text { billion (initial capitalization } \$ 10 \text { billion, } \\
65 \% \text { from foreign reserve, } 15 \% \text { from China Investment } \\
\text { Corporation, } 15 \% \text { from EXIM Bank, } \\
\text { and } 5 \% \text { from China Development Bank) }\end{array}$ \\
\hline $\begin{array}{l}\text { China-Kazakhstan Production } \\
\text { Capacity Cooperation Fund }\end{array}$ & 2016 & $\$ 2$ billion (from Silk Road Fund) \\
\hline China-Africa Cooperation Fund & 2015 & $\$ 10$ billion (Foreign reserve $80 \%+$ EXIM Bank $20 \%$ ) \\
\hline China-LAC Cooperation Fund & 2016 & $\$ 30$ billion (initial capitalization $\$ 10$ billion) \\
\hline $\begin{array}{l}\text { China-Brazil Cooperation Fund for the } \\
\text { Expansion of Production Capacity }\end{array}$ & 2017 & $\begin{array}{l}\text { Up to } \$ 20 \text { billion ( } \$ 15 \text { billion from China-LAC } \\
\text { Cooperation Fund and } \$ 5 \text { billion from Brazil) }\end{array}$ \\
\hline
\end{tabular}

Sources: Compiled by the author.

development engagements. China argues that its approach to international development cooperation reflects the spirit of South-South Cooperation and thus is morally superior to the one-way aid given by countries of the North. However, the ICECs' mandate to promote the export and entrenchment of China's industrial capacity and technical standards follows a logic hardly different from the traditional North-South relationship, in which the advanced industrialised economies occupy advantageous positions in the global value chain, solidifying asymmetrical economic relations in which the less advanced economies have little autonomy.

To sustain their business, Chinese ICECS are currently seeking to transform their role from contractors into developers. This can have profound implications for their relations with host countries. Unlike EPC contracting, in which ICECs' interactions with local society tended to be limited and temporary, as developers of large-scale infrastructure and industrial projects, they will need to become embedded in the local socio-economic landscape and nurture deeper relations with various local stakeholders beyond the government. As such, it may be inevitable for them to become entangled in local politics, which will call into question China's noninterference principle in international development cooperation. It has already been observed in Myanmar, where Chinese ICECs have significant presence including as investors, that the non-interference principle has come under serious challenge (Zou and Jones 2020).

As Chinese ICECs become even more powerful players in the global market, the tension between their commercial interests and China's foreign policy goals may become more pronounced. As explained earlier, the ICECs' pursuit of unviable projects has already caused China reputational damage. For their raison d'être, they will continue to push for industrialisation and infrastructural development in the developing world, which may come at the cost of a more balanced and sustainable development, and ultimately harm the Chinese state's ambition to be a global public good provider.

It has been argued that the Chinese state's capacity to monitor and regulate the SOEs in overseas markets was quite limited (Xu 2014). A main reason is the fragmentation in the oversight authority, which leaves room for the SOEs' self-interested behaviour, sometimes at the expense of the state (Liou 2014). Nevertheless, there is evidence that the state has been trying to strengthen regulatory oversight over the ICECs: since 2015, participation in the tendering of any project worth over 5 million dollars requires pre-approval from the Chinese embassy's Economic and Commercial Office. Projects will be evaluated based on criteria including their consistency with China's overall trade policy and anticipated political risks. ${ }^{23}$ The establishment of the China International Development Cooperation Agency (CIDCA) in 2018 represents another attempt by the state to impose more centralised control over international development activities and reduce the autonomy of ICECs in reverse-engineering their commercial pursuits into aid projects. However, the relatively weak position of the agency in China's administrative system, in addition to bureaucratic inertia, means that substantial changes in the aid processes are slow to happen ${ }^{24}$ (Zhao and jing 2019). In the foreseeable future, we are likely to see ICECs continue to advance their interests as they try to fulfil their state-mandated mission of "Going out" and facilitating export of China's industrial capacities, but at the same time also creating new challenges for the state. The state may be trying to catch up in its oversight and control, but it is inevitably lagging and reactive.

\section{Acknowledgements}

I The author wishes to thank the organisers and participants of the "Chinese Global Engagement Aboard: Changing Social, Economic and Political Configurations" conference in July 2019 at the Hong Kong University of Science and Technology, where an earlier draft of this paper was presented and received constructive feedback, in particular from Dr. June Wang. The author also thanks the two anonymous reviewers and the editorial committee of China Perspectives for their comments that helped improve the paper.

I Hong Zhang is a PhD candidate in public policy at Schar School of Policy and Government, George Mason University, United States (hzhang14@ masonlive.gmu.edu).

Manuscript received on 2 October 2019. Accepted on 14 August 2020.

23. “關于駐外經商機構為企業辦理對外承包工程項目投標 (議標) 核准意見的暫行規定” (Guanyu zhuwai jingshang jigou wei qiye banli duiwai chengbao gongcheng xiangmu toubiao (yibiao) hezhun yijian de zanxing guiding, Interim rules on overseas economic and commercial offices' approving opinions for companies to participate in tendering (negotiated tendering) in international contracting projects), Chinese Ministry of Commerce, 10 October 2015, http://hzs. mofcom.gov.cn/article/zcfb/a/201612/20161202110143.shtml (accessed on 20 March 2020).

24. Marina Rudyak, "The Ins and Outs of China's International Development Agency - Carnegie Endowment for International Peace," Carnegie-Tsinghua Center for Clobal Politics, 2 September 2019, https://carnegieendowment.org/2019/09/02/ins-and-outs-of-china-s-internationaldevelopment-agency-pub-79739 (accessed on 15 March 2020). 


\section{Primary sources}

YEARBOOK OF FOREIGN ECONOMY AND TRADE OF CHINA 中國對外經濟貿易年鑒 (Zhongguo duiwai jingji maoyi nianjian). 1989, 1992， 1994, 1995, 1996, 1997, 1998, 2000. Beijing: Zhongguo duiwai jingji maoyi chubanshe.

\section{References}

ALVES, Ana Cristina. 2013. "China's 'Win-Win' Cooperation: Unpacking the Impact of Infrastructure-for-Resources Deals in Africa." South African Journal of International Affairs 20(2): 207-26.

BERSCH, Katherine, and Riitta-Ilona KOIVUMAEKI. 2019. "Making Inroads: Infrastructure, State Capacity, and Chinese Dominance in Latin American Development." Studies in Comparative International Development 54(3): 323-45.

BIAN, Yanling 市延齡. 2013. “關于加納優惠貸款項目的實踐體會." (Guanyu Jiana youhui daikuan xiangmu de shijian tihui, Experience and thoughts on preferential loan projects in Chana). 國際工程與勞 務 (Guoji gongcheng yu laowu, International Engineering and Labour Services) 7: 48-9.

BLUHM, Richard, Axel DREHER, Andreas FUCHS, Bradley PARKS, Austin STRANGE, and Michael TIERNEY. 2018. "Connective Financing: Chinese Infrastructure Projects and the Diffusion of Economic Activity in Developing Countries." Working Paper 64. AidData.

BRAUTIGAM, Deborah. 2011. "Aid 'With Chinese Characteristics': Chinese Foreign Aid and Development Finance Meet the OECD-DAC Aid Regime." Journal of International Development 23(5): 752-64.

BRAUTIGAM, Deborah, and Jyhjong HWANG. 2019. "Great Walls over African Rivers: Chinese Engagement in African Hydropower Projects." Development Policy Review 37(3): 313-30.

CHANG, Jian 常鑒. 2015. "2015 年對外承包工程業務發展建議" (2015 nian duiwai chengbao gongcheng yewu fazhan jianyi, Suggestions for the development of the international contracting business in 2015). 國際工程與勞務 (Guoji gongcheng yu laowu, International Engineering and Labour Services) 4: 24-6.

CHEN, Chuan, Pi-Chu CHIU, Ryan J. ORR, and Andrea GOLDSTEIN 2007. "An Empirical Analysis of Chinese Construction Firms' Entry into Africa." Conference paper, International Symposium on Advancement of Construction Management and Real Estate, 8-13 August, Sydney Australia.

CHEN, Chuan, Andrea GOLDSTEIN, and Ryan J. ORR. 2009. "Local Operations of Chinese Construction Firms in Africa: An Empirical Survey." International Journal of Construction Management 9(2): 75-89.

CHEN, Chuan, and Ryan J. ORR. 2009. "Chinese Contractors in Africa: Home Government Support, Coordination Mechanisms, and Market Entry Strategies." Journal of Construction Engineering and Management 135(11): 1201-10.
CHEN, Chuan, Qi WANG, Igor MARTEK, and Hongjiang LI. 2016. "International Market Selection Model for Large Chinese Contractors." Journal of Construction Engineering and Management 142(10): 1-11.

CHEN, Muyang. 2018. "Official Aid or Export Credit: China's Policy Banks and the Reshaping of Development Finance." Working Paper 001. GCI Working Paper. Clobal Development Policy Center, Boston University.

CHIN, Gregory T., and Kevin P. GALLAGHER. 2019. "Coordinated Credit Spaces: The Globalization of Chinese Development Finance." Development and Change 50(1): 245-74.

CORKIN, Lucy. 2011. "Uneasy Allies: China's Evolving Relations with Angola." Journal of Contemporary African Studies 29(2): 169-80.

EDITORIAL BOARD. 2017. “以參與者身份融入當地發展” (Yi canyuzhe shenfen rongru dangdi fazhan, Getting involved in local development as stakeholders). 國際工程與勞務 (Guoji gongcheng yu laowu, International Engineering and Labour Services) 11.

FOSTER, Vivien, William BUTTERFIELD, and Chuan CHEN. 2009. Building Bridges: China's Growing Role as Infrastructure Financier for Africa. Washington: The World Bank.

GALLAGHER, Keven P., Amos IRWIN, and Katherine KOLESKI. 2012. "The New Banks in Town: Chinese Finance in Latin America." Report of the Inter-American Dialogue China and Latin America Working Group: 1-37.

GU, Jing, and Naohiro KITANO. 2018. "Introduction: Beyond Aid - The Future of Development Cooperation." IDS Bulletin 49(3): 1-11.

GU, Jing, Xiaoyun LI, Gerald BLOOM, and Xiulan ZHANG. 2014. "Introduction: China and International Development: Challenges and Opportunities." IDS Bulletin 45(4): 1-5.

HUANG, Meibo, and Peiqiang REN. 2012. "China's Foreign Aid and Its Role in the International Architecture." International Development Policy 3(3). doi.org/10.4000/poldev.1004.

JIANG Huajie 蔣華杰. 2019. “現代化, 國家安全與對外援助 - 中國 援非政策演變再思考 (1970-1983)” (Xiandaihua, guojia anquan yu duiwai yuanzhu - Zhongguo Yuanfei zhengce yanbian zai sikao (19701983), Modernization, National Security and Foreign Aid - Revisiting China's Aid to Africa (1970-1983)). 外交評論 (Waijiao pinglun, Foreign policy review) 6: 121-54.

JIANG, Liqin 江立勤. 2016. “國家戰略級的頂層融資設計” (Guojia zhanlüeji de dingceng rongzi sheji, National strategic top-level design of financing). 國際工程與勞務 (Guoji gongcheng yu laowu, International Engineering and Labour Services) 2: 30-2. 
JOHNSTON, Lauren, and Marina RUDYAK. 2017. "China's 'Innovative and Pragmatic' Foreign Aid: Shaped by and Now Shaping Clobalisation." In Ligang Song, Ross Garnaut, Fang Cai, and Lauren Johnston (eds.), China's New Sources of Economic Growth: Human Capital, Innovation and Technological Change. Canberra: ANU Press. 431-52.

JONES, Lee, and Yizheng ZOU. 2017. "Rethinking the Role of StateOwned Enterprises in China's Rise." New Political Economy 22(6): 74360 .

KAPLAN, Stephen B. 2016. "Banking Unconditionally: The Political Economy of Chinese Finance in Latin America." Review of International Political Economy 23(4): 643-76.

KITANO, Naohiro. 2018. "Estimating China's Foreign Aid Using New Data." IDS Bulletin 49(3): 49-72.

LI, Chen. 2016. "Holding 'China Inc.' Together: The CCP and The Rise of China's Yangqi." The China Quarterly 228(December): 927-49.

LI, Xiaoyun, Dan BANIK, Lixia TANG, and Jin WU. 2014. "Difference or Indifference: China's Development Assistance Unpacked." IDS Bulletin 45(4): 22-35.

LIN, Justin Yifu, and Yan WANG. 2016. Going beyond Aid: Development Cooperation for Structural Transformation. Cambridge: Cambridge University Press.

LIOU, Chih-shian. 2009. "Bureaucratic Politics and Overseas Investment by Chinese State-Owned Oil Companies: Illusory Champions." Asian Survey 49(4): 670-90.

LIOU, Chih-shian. 2014. "Rent-Seeking at Home, Capturing Market Share Abroad: The Domestic Determinants of the Transnationalization of China State Construction Engineering Corporation." World Development 54(February): 220-31.

LIU, Xueqiang 劉雪强. 2015. “促進中國工程建設標準和規範 '走 出去”' (Cujin Zhongguo gongcheng jianshe biaozhun he guifan "zou chuqu", Promoting the "Coing out" of Chinese engineering and construction standards and rules). 國際工程與勞務 (Guoji gongcheng yu laowu, International Engineering and Labour Services) 1:65-6.

MORGAN, Pippa. 2019. "Can China's Economic Statecraft Win Soft Power in Africa? Unpacking Trade, Investment and Aid." Journal of Chinese Political Science 24(3): 387-409.

MORGAN, Pippa, and Yu ZHENG. 2019. "Old Bottle New Wine? The Evolution of China's Aid in Africa 1956-2014." Third World Quarterly 40(7): 1283-303.

NAUGHTON, Barry. 2015. "The Transformation of the State Sector: SASAC, the Market Economy, and the New National Champions." In Barry Naughton and Kellee S. Tsai (eds.), State Capitalism, Institutional Adaptation, and the Chinese Miracle. Cambridge: Cambridge University Press. 46-74.

SANDERSON, Henry, and Michael FORSYTHE. 2013. China's Superbank: Debt, Oil and Influence; How China Development Bank Is Rewriting the Rules of Finance. Bloomberg. Singapore:Wiley.
SHI, Xuefei, and Paul HOEBINK. 2020. "From Chengdu to Kampala: The Role of Subnational Actors in China's Foreign Aid." Journal of Contemporary China 29(121): 125-40.

SHIMOMURA, Yasutami, and Ping WANG. 2018. "Chains of Knowledge Creation in the Evolution of New Donors." IDS Bulletin 49(3).

SUN, Xin 孫金金. 2015. “中國標準助推高鐵 “走出去”' (Zhongguo biaozhun zhutui gaotie "zou chuqu", Chinese standards help with "Going out" of hi-speed railway). 國際工程與勞務 (Guoji gongcheng yu laowu, International Engineering and Labour Services) 7:63-5.

TAN-MULLINS, May, Giles MOHAN, and Marcus POWER. 2010. "Redefining 'Aid' in the China-Africa Context." Development and Change 41(5): 857-81.

TIERNEY, Michael J., Daniel L. NIELSON, Darren G. HAWKINS, J.Timmons ROBERTS, Michael G. FINDLEY, Ryan M. POWERS, Bradley PARKS, Sven E. WILSON, and Robert L. HICKS. 2011. "More Dollars than Sense: Refining our Knowledge of Development Finance Using AidData." World Development 39(11): 1891-906.

WANG, Yan 王琰. 2018. “一帶一路'海外基建項目融資模式分析” ("Yidai yilu" haiwai jijian xiangmu rongzi moshi fenxi, Analysis on the financing models in overseas infrastructure projects under "Belt and Road"). 國際融資 (Guoji rongzi, International financing) March: 54-7.

WOODS, Ngaire. 2008. "Whose Aid? Whose Influence? China, Emerging Donors and the Silent Revolution in Development Assistance." International Affairs 84(6): 1205-21.

XU, Yi-chong. 2014. "Chinese State-Owned Enterprises in Africa: Ambassadors or Freebooters?" Journal of Contemporary China 23(89): $822-40$

YANKSON, Paul W. K., Alex B. ASIEDU, Kwadwo OWUSU, Frauke URBAN, and Giuseppina SICILIANO. 2018. "The Livelihood Challenges of Resettled Communities of the Bui Dam Project in Chana and the Role of Chinese Dam-Builders." Development Policy Review 36(March): 476-94.

ZHANG, Denghua, and Graeme SMITH. 2017. "China's Foreign Aid System: Structure, Agencies, and Identities." Third World Quarterly 38(10): 2330-46.

ZHANG, Hong. 2019. "Beyond 'Debt-Trap Diplomacy':The Dissemination of PRC State Capitalism." China Brief 19(1). https://jamestown.org/ program/beyond-debt-trap-diplomacy-the-dissemination-of-prc-statecapitalism/ (accessed on 2 September 2020).

ZHAO, Jianzhi, and Yijia JING. 2019. "The Governance of China's Foreign Aid System: Evolution and Path Dependence." Public Administration and Development 39(4-5): 182-92.

ZHOU, Hong 周弘, and Hou XIONG 熊厚 (eds.). 2013. 中國援外60年 (Zhongguo yuanwai 60 nian, China's Foreign Aid: 60 Years in Retrospect). Beijing: Shehui kexue wenxian chubanshe.

ZOU, Yizheng, and Lee JONES. 2020. "China's Response to Threats to Its Overseas Economic Interests: Softening Non-Interference and Cultivating Hegemony." Journal of Contemporary China 29(121): 92108. 